\title{
Recenzja
}

\section{O demokracji w polskich partiach politycznych, pod red. Marka Chmaja, Marcina Waszaka, Jarosława Zbieranka, Instytut Spraw Publicznych, Konrad Adenauer Stiftung, Warszawa 201 1, ss. 200}

Problematyka partii politycznych, ich tworzenia, finansowania oraz zasad ich funkcjonowania $\mathrm{w}$ życiu publicznym stanowi zagadnienie stosunkowo dobrze opisane w literaturze przedmiotu. Innymi słowy, możemy przyjąć, że swoiste „zewnętrze” funkcjonowanie partii politycznych stanowi relatywnie intensywnie uregulowany prawem przedmiot oraz dobrze opisane zagadnienie. Natomiast wciąż nie sposób tego powiedzieć o funkcjonowaniu mechanizmów wewnątrzpartyjnych.

W studiach nad partiami politycznymi od dawna dawało się odczuć pewną dysproporcję między licznymi badaniami nad rolą i funkcjami partii politycznych w życiu publicznym, w tym w sprawowaniu przez nie władzy, a deficytem opracowań dotyczących zagadnień związanych z wewnątrzpartyjną demokracją lub jej brakiem. Decyzja o podjęciu takich właśnie badań, siłą rzeczy zmierzających do złagodzenia wspomnianej dysproporcji, oznacza dla prawnika między innymi potrzebę wgłębienia się w powszechnie nieobowiązujące, wewnętrzne prawo poszczególnych partii, to jest ich statutów, innych uchwał odpowiednich organów partii itp. Takie opracowanie, oparte wyłącznie na wewnątrzpartyjnym materiale normatywnym, zapewne byłoby pożyteczne, chociażby ze względu na jego porównawczy wymiar.

Jednak w moim przekonaniu prezentacja wewnętrznych mechanizmów funkcjonowania partii politycznych, w tym ocena poziomu demokratyzmu tych mechanizmów, przeprowadzona wyłącznie w oparciu o prawne, w tym wewnątrzpartyjne regulacje, sprawiałaby wrażenie niepełnej. Dlatego uważam, że realizacja zamiaru zbadania sposobu działania partii politycznych, ich organów oraz - co szczególnie istotne - praktyka poszczególnych szczebli partyjnych struktur wymagają włączenia do badań - obok prawników konstytucjonalistów - także przedstawicieli innych dyscyplin nauki, a zwłaszcza politologów i socjologów. W przypadku recenzowanej pozycji 
tak właśnie się stało, zespół autorski objął bowiem prawnika konstytucjonalistę - prof. Marka Chmaja, dwóch politologów - dr. Marcina Waszaka i dr. Jarosława Zbieranka oraz socjologa - dr. Jarosława Flisa. Konsekwencją tego trafnego kadrowo-zawodowego założenia jest powstanie opracowania dostarczającego wielopłaszczyznowego i możliwie pełnego oglądu zagadnienia demokracji w polskich partiach politycznych. Myśl o łącznym ujęciu zagadnienia demokracji w polskich partiach politycznych w płaszczyznach prawnej, politycznej i socjologicznej doznała rozwinięcia w kompetencji uczestników i przebiegu seminarium pt. Ile demokracji $w$ polskich partiach politycznych?, którego zapis stanowi część recenzowanej pozycji.

Pierwszą część pracy stanowi obszerne opracowanie M. Chmaja pt. Prawne aspekty demokracji wewnątrzpartyjnej. Jest to analiza prawna skupiająca się na odpowiednich regulacjach konstytucyjnych, ustawowych, wewnątrzpartyjnych oraz orzecznictwie Trybunału Konstytucyjnego. Po krótkiej prezentacji konstytucyjnych i ustawowych podstaw działalności partii politycznych. Autor przedstawia zasady ich działania, w tym zasadę zrzeszania na zasadzie dobrowolności i równości, zasadę jawności finansowania partii politycznych, zasadę zakazu istnienia partii, których program lub działalność są sprzeczne z Konstytucją RP, zasadę równego traktowania partii przez organy władzy publicznej, zasadę zapewnienia partiom dostępu do publicznej radiofonii i telewizji na zasadach określonych w odrębnych ustawach, zasadę oddzielenia struktur partii od organów władzy publicznej oraz kwestię ukształtowania struktur i zasad działania partii zgodnie z zasadami działania demokracji. Sporo uwagi Autor poświęcił - co uważam za szczególnie wartościowe - regulacjom statutowym demokracji wewnątrzpartyjnej. W tym zakresie omówił istotę statutu partii politycznej oraz warunki uzyskania członkostwa w partii politycznej. Toczy także rozważania o przyjęciu do partii politycznej, o przesłankach ukarania karą dyscyplinarną i o katalogu kar dyscyplinarnych oraz o utracie członkostwa w partii politycznej.

Obok prezentacji i omówienia stanu prawnego dotyczącego ww. zakresu zagadnień, M. Chmaj dokonuje szeregu zestawień, porównań, a także sygnalizuje istnienie problemów i rozwiązań w ocenie doktryny niejednoznacznych, kontrowersyjnych, a przez to interesujących. Przykładowo, analizując warunki uzyskania ${ }^{1}$ członkostwa w partii politycznej (s. 31-32), Autor dokonuje zestawienia i omówienia pojęć: nieposzlakowana opinia, nieska-

1 A logicznie należałoby dodać: „i jego utrzymania”. 
zitelny charakter czy nienaganna opinia. Słusznie zauważa, że żadne z powyższych pojęć nie jest w sposób jednoznaczny zdefiniowane. Wydaje się, że pojęcia te obejmują wymóg postępowania zgodnego z zasadami współżycia społecznego czy etyki zawodowej. Natomiast trudno byłoby mówić o objęciu tymi pojęciami wymogu postępowania moralnego, w tym zachowania moralnego w kontekście obyczajowym. A to z dwóch powodów. Po pierwsze, w ogólnym odbiorze społecznym polityka nie jest traktowana jako zajęcie i działalność z założenia moralna. Po drugie, w społeczeństwie funkcjonują bardzo różne systemy moralne, w tym różne poglądy na kwestie obyczajowe. Kwestie obyczajowe zatem powinny być z tych rozważań wyłączone. Poglądowi temu sprzyjają obecne tendencje społeczne, które nota bene znalazły nowy, mocny wyraz w wynikach ostatnich wyborów parlamentarnych. W ostatnim czasie polska obyczajowość znacząco przeewoluowała, co powinno wpłynąć na prawodawcę, stosujących prawo oraz na jego interpretatorów. Społeczna zgoda co do potrzeby respektowania norm moralnych ogranicza się w zasadzie do elementarnych norm moralnych, a te najczęściej znajdują swój wyraz normatywny. Ich istotą jest zakaz wyrządzania krzywdy drugiemu człowiekowi. Natomiast należy zgodzić się ze stanowczo wyrażonym przez Autora poglądem, że osoba, której postawiono zarzuty lub w stosunku do której toczy się postępowanie karne, nie może być osobą o nieposzlakowanej opinii.

Wiarygodnego obrazu stanu wewnątrzpartyjnej demokracji w Polsce dostarcza empiryczna część pracy stworzona przez M. Waszaka, a zatytułowana Polskie partie $w$ badaniach ankietowych Instytutu Spraw Publicznych. Podmiotowym zakresem badania zostały objęte partie polityczne Sejmu VI kadencji. Przedmiotowy zakres badania objął model dystrybucji władzy w partii. Badano kwestie równości dostępu do kierowniczych stanowisk, wewnątrz partyjnych kanałów komunikacyjnych, uczestnictwa członków partii w procesach decyzyjnych, w tym w układaniu list wyborczych, kolegialnego wyboru władz i kandydatów na stanowiska publiczne, gwarancji pluralizmu oraz egzekwowania praw członków partii. Ankieta objęła 24 pytania. Została skierowana do partyjnych centrali, które współpracowały z badaczami z różną intensywnością i zaangażowaniem, a jedna z partii politycznych (PiS) odmówiła współpracy. Wyniki ankiety zostały przedstawione w postaci tabelarycznej. Każdej z tabel wyników towarzyszy profesjonalny komentarz. 
Pewnym rozwinięciem tej doświadczalnej części pracy jest jej kolejna część w postaci zapisu seminarium pt. Ile demokracji w polskich partiach politycznych. Jego uczestnikami byli: prof. Andrzej Antoszewski, dr Mikołaj Cześnik, dr Jarosław Flis, dr Marek Jarentowski, prof. Radosław Markowski, dr Anna Materska-Sosnowska, dr Bartłomiej Michalak, dr Bartłomiej Nowotarski, prof. Katarzyna Sobolewska-Myślik oraz prof. Wojciech Sokół. Seminarium to odbyło się dnia 5 kwietnia 2011 r. w Instytucie Spraw Publicznych.

Autor czwartej części opracowania J. Flis uznaje, że wątpliwy poziom wewnątrzpartyjnej demokracji jest efektem splotu uwarunkowań instytucjonalnych, wewnętrznych i zewnętrznych. Przedstawiając meandry labiryntu demokracji wewnątrzpartyjnej, J. Flis omawia zagadnienia głosowania blokowego, awansu w wyborach powszechnych, znaczenia głosu preferencyjnego, alternatyw dla głosowania blokowego oraz zagadnienie wyborów posłów.

Reasumując, otrzymujemy do ręki pozycję wartościową. Jest to pierwsza publikacja tak szeroko i wieloaspektowo traktująca o wewnętrznych mechanizmach demokratycznych w polskich partiach politycznych. Wytycza ona pewien kierunek, ale i sposób badań, które powinny być kontynuowane.

Autorzy formułują określone wnioski-rekomendacje dotyczące kondycji i postulatów zmian w polskich partiach politycznych. Kluczowe jest stwierdzenie zasadniczo niskiego poziomu wewnętrznych partyjnych procedur demokratycznych, co wywiera negatywny wpływ na poziom polskiego życia publicznego. W naszych partiach dostrzegalne jest zjawisko cartel party, objawiające się dążeniu do maksymalizacji spójności partii politycznej poprzez realizację silnego przywództwa, minimalizację różnic zdań i tłumienie wewnętrznej konkurencji. Instrumentów poprawy tego stanu rzeczy Autorzy upatrują między innymi w ograniczeniu partyjnego centralizmu, instytucji prawyborów czy w wyborze przewodniczącego przez wszystkich członków partii, a nie przez ciała przedstawicielskie.

Przedstawiona całość dokonań została uzupełniona przez pięć aneksów, których merytoryczna zawartość dobrze koresponduje z zasadniczą częścią publikacji. Dwa z nich to wzór ankiety oraz wyniki ankiet przeprowadzonych wśród największych polskich partii politycznych. Trzeci aneks dostarcza interesującego zestawienia trybów podejmowania decyzji w świetle statutów i regulaminów partii politycznych. Kolejne aneksy zawierają treść ustawy o partiach politycznych oraz projekt ustawy Prawo o partiach poli- 
tycznych autorstwa M. Chmaja. M. Chmaj proponuje kilka istotnych zmian w obowiązującym stanie prawnym. Między innymi słusznie opowiada się za zniesieniem racjonalnie nieuzasadnionego zakazu wstępowania do partii politycznych osób zatrudnionych w takich grupach zawodowych, jak pracownicy służby więziennej czy miejscy i gminni strażnicy.

Recenzowana pozycja stanowi owoc realizacji projektu badawczego $\mathrm{Me}$ chanizmy demokratyczne wewnatrz partii politycznych $w$ Polsce, realizowanego w Programie Prawa i Instytucji Demokratycznych Instytutu Spraw Publicznych, przy wsparciu finansowym Fundacji Konrada Adenauera w Polsce. Szefem zespołu projektowego był M. Chmaj.

Andrzej Bisztyga (Uniwersytet Śląski w Katowicach) 